\title{
Discrimination of infectious hepatitis A virus and rotavirus by combining dyes and surfactants with RT-qPCR
}

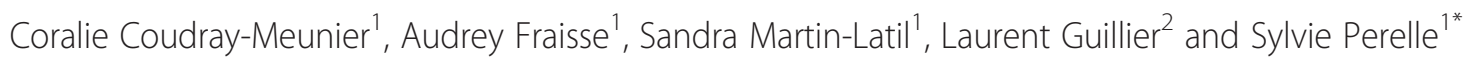

\begin{abstract}
Background: Human enteric viruses are major agents of foodborne diseases. Because of the absence of a reliable cell culture method for most of the enteric viruses involved in outbreaks, real-time reverse transcriptase PCR is now widely used for the detection of RNA viruses in food samples. However this approach detects viral nucleic acids of both infectious and non infectious viruses, which limits the impact of conclusions with regard to public health concern. The aim of the study was to develop a method to discriminate between infectious and non-infectious particles of hepatitis A virus (HAV) and two strains of rotavirus (RV) following thermal inactivation by using intercalating dyes combined with RT-qPCR.

Results: Once the binding of propidium monoazide (PMA) or ethidium monoazide (EMA) was shown to be effective on the viral ssRNA of HAV and dsRNA of two strains of RV (SA11 and Wa), their use in conjunction with three surfactants (IGEPAL CA-630, Tween 20, Triton X-100) prior to RT-qPCR assays was evaluated to quantify the infectious particles remaining following heat treatment. The most promising conditions were EMA $(20 \mu \mathrm{M})$ and

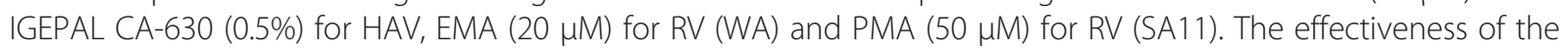
pre-treatment RT-qPCR developed for each virus was evaluated with three RT-qPCR assays $(A, B, C)$ during thermal inactivation kinetics (at $37^{\circ} \mathrm{C}, 68 \mathrm{C}, 72^{\circ} \mathrm{C}, 80^{\circ} \mathrm{C}$ ) through comparison with data obtained by RT-qPCR and by infectious titration in cell culture. At $37^{\circ} \mathrm{C}$, the quantity of virus (RV, HAV) remained constant regardless of the method used. The genomic titers following heat treatment at $68^{\circ} \mathrm{C}$ to $80^{\circ} \mathrm{C}$ became similar to the infectious titers only when a pre-treatment RT-qPCR was used. Moreover, the most effective decrease was obtained by RT-qPCR assay A or B for HAV and RT-qPCR assay B or C for RV.

Conclusions: We concluded that effectiveness of the pre-treatment RT-qPCR is influenced by the viral target and by the choice of the RT-qPCR assay. Currently, it would be appropriate to further develop this approach under specific conditions of inactivation for the identification of infectious viruses in food and environmental samples.
\end{abstract}

Keywords: Propidium monoazide, Ethidium monoazide, Surfactant, RT-qPCR, Hepatitis A virus, Rotavirus, Thermal inactivation, Infectivity

\section{Background}

Food-borne enteric viruses, particularly human noroviruses $(\mathrm{NoV})$, rotaviruses (RV) and hepatitis A virus (HAV), constitute a serious public health concern, since they are responsible for the vast majority of cases of non-bacterial gastroenteritis and infectious hepatitis, which may occasionally be fatal $[1,2]$. These viruses are able to replicate in

\footnotetext{
* Correspondence: sylvie.perelle@anses.fr

${ }^{1}$ ANSES, Food Safety Laboratory, Food and Water Virology Unit, 23 Avenue

du Général de Gaulle, 94706 Maisons-Alfort cedex, France

Full list of author information is available at the end of the article
}

the human gastro-intestinal tract and are dispersed by shedding in high concentrations into the stools. The stability of these viruses with regard to several physical conditions such as $\mathrm{pH}$ and temperature, and their resistance to different treatment systems, contribute significantly to their persistence in the environment [3,4]. Transmission of these viruses occurs by the faecal-oral route, primarily through direct person-to-person contact, but they are also efficiently transmitted by ingestion of contaminated drinking water or contaminated foods such as raw shellfish, fresh fruits and vegetables [5].

\section{C) Biomed Central}

(c) 2013 Coudray-Meunier et al.; licensee BioMed Central Ltd. This is an Open Access article distributed under the terms of the Creative Commons Attribution License (http://creativecommons.org/licenses/by/2.0), which permits unrestricted use, distribution, and reproduction in any medium, provided the original work is properly cited. 
To ensure the safety of these products, the development of sensitive, reliable techniques for the detection of enteric viruses in food and water samples is helpful. The cell culture system is the gold standard to examine the infectivity of the isolated viruses. Currently, detection of the main enteric viruses on the basis of their infectivity is complicated by the absence of a reliable cell culture method and the low contamination levels of food samples. Thus, molecular methods have been developed for the rapid detection of viral contamination of foods [6,7]. In 2004, the European Committee for Standardisation (CEN) asked a technical advisory group (TAG4) to develop standard methods (qualitative / quantitative) for the detection of norovirus and HAV in foodstuffs. Standard methods have recently been elaborated for a range of risk foods including bottled water, soft fruits and vegetables. The CEN/ISO/TS 15216 standard was published in the first half of 2013 and within a year these proposed protocols will be validated and then published as ISO or CEN standard methods [8]. All these methods are based on a final detection of the viral genome using real-time reverse transcriptase PCR (RT-qPCR), used for its sensitivity, specificity, speed and ability to deliver quantitative data. However, this approach detects the viral nucleic acids of both infectious and non-infectious viruses.

Therefore, it is important to develop and evaluate simple and efficient tools which make it possible to overcome the limitations of the traditional cell culture and PCR assays [9]. An approach based on an enzymatic treatment with RNAse combined with a proteinase $\mathrm{K}$ treatment was found to be successful in some cases in distinguishing between infectious and non-infectious viruses [10-12]. For bacteria, a relatively recent approach is the treatment of samples with the DNA-intercalating dyes ethidium monoazide (EMA) or propidium monoazide (PMA) [13-17]. EMA and PMA are closely related DNA intercalating dyes with a photo-inducible azide group that covalently cross-link to DNA through visible-light photoactivation. PMA has the advantage of being more selective than EMA for dead cells as it is more membrane-impermeant [18]. Recently, promising PMA / EMA treatments have also been tested for distinguishing between infectious and non-infectious RNA viruses $[19,20]$. A study concluded that PMA-RT-PCR assays that include pretreatment of enteroviruses and noroviruses with PMA prior to RT-PCR enable rapid differentiation between infectious and non-infectious enteric viruses when the virus particles are inactivated by heating at $72^{\circ} \mathrm{C}$ or $37^{\circ} \mathrm{C}$ or by using hypochlorite. However, unlike poliovirus, PMA treatment did not affect detection of heatinactivated Norwalk virus by quantitative RT-PCR [21]. Another study found that EMA did not distinguish between infectious and non-infectious avian influenza virus particles [22]. Sánchez et al. [23] showed that PMA treatment previous to RT-qPCR detection is a promising alternative for assessing HAV infectivity.
The usefulness of EMA or PMA for distinguishing between infectious and non-infectious RV and HAV was investigated. Both viruses were chosen for their cultivability and their differences in genomic organization. RV, the leading cause of severe dehydrating diarrhea in infants and young children worldwide, are non-enveloped viruses that possess a genome with 11 segments of double-stranded RNA contained in a triple-layered protein capsid and belong to the Reoviridae. Hepatitis A virus (HAV) infection is the leading worldwide cause of acute viral hepatitis. HAV is a positive single-stranded non-enveloped RNA virus classified in the Hepatovirus genus of the Picornaviridae family.

The purpose of this study was to develop a method based on pre-treatment-RT-qPCR assays in order to discriminate between infectious and non-infectious viruses (HAV, RV) following thermal inactivation. To this end, the binding of EMA and PMA to RV and HAV RNA was investigated. Then, a pre-treatment based on "PMA or EMA +/- surfactant RT-qPCR" was optimized for each virus. Finally, this method was applied to establish viral thermal inactivation kinetics through three RT-qPCR assays.

\section{Results}

\section{Standard curves of RT-qPCR assays on viral RNA}

Linear regression analyses were performed by plotting the cycle threshold $(\mathrm{Ct})$ values against the logarithm of the PFU of HAV or $\mathrm{TCID}_{50}(50 \%$ tissue culture infectious dose) of RV (SA11 and Wa) with RT-qPCR assays A, B and $C$ corresponding to the RNA target. The mean parameters of the standard curves were as follows: standard curves respectively obtained with HAV assays A, B and C showed efficiencies of $100.00 \%, 95.93 \%$, and $104.83 \%$ and regression coefficients of $0.999,0.997,0.996$; standard curves respectively obtained with RV assays A, B and C showed efficiencies of $90.93 \%, 94.03 \%$, and $94.23 \%$ and regression coefficients of $0.993,0.986,0.976$ with Wa; standard curves respectively obtained with RV assays A, B and C showed efficiencies of $78.83 \%, 76.53 \%$, and $85.50 \%$ and regression coefficients of $0.989,0.984,0.989$ with SA11.

\section{Evaluation of dyes-RT-qPCR assays on viral RNA}

The first experiments studied the efficiency of PMA and EMA treatments to bind the viral RNA in order to avoid its detection (RV, HAV) using RT-qPCR assays A and the potential inhibitory effects of the dyes on RT-qPCR amplification (Table 1). Viral RNA was treated with dye concentrations ranging from 10 to $200 \mu \mathrm{M}$ without photoactivation and then subjected to RT-qPCR to determine if residual dyes can be inhibitors for RT-qPCR (Table 1A). In the lowest PMA concentration $(10 \mu \mathrm{M})$, an inhibitory effect on RT-qPCR detection was only found for RV RNA (Wa and SA11) (respectively a decrease of $-0.87 \log _{10}$ and $-1.47 \log _{10}$ of detected RNA). 
Table 1 Binding of dyes to purified viral RNA

\begin{tabular}{|c|c|c|c|c|c|c|}
\hline \multirow{2}{*}{$\begin{array}{c}\text { [Dye] } \\
\mu \mathrm{M}\end{array}$} & \multicolumn{2}{|c|}{ HAV } & \multicolumn{2}{|c|}{ RV (Wa) } & \multicolumn{2}{|c|}{ RV (SA11) } \\
\hline & PMA & EMA & PMA & EMA & PMA & EMA \\
\hline \multicolumn{7}{|l|}{ A } \\
\hline 10 & $-0.09 \pm 0.11$ & $-0.12 \pm 0.09$ & $-0.87 \pm 0.30$ & $-0.52 \pm 0.19$ & $-1.47 \pm 1.27$ & $-0.41 \pm 0.27$ \\
\hline 20 & $-1.59 \pm 0.74$ & $-0.21 \pm 0.27$ & -1.87 & $-1.18 \pm 0.46$ & $-2.51 \pm 0.69$ & $-0.31 \pm 0.31$ \\
\hline 50 & $<\mathrm{LOD}$ & $-0.99 \pm 0.51$ & $<\mathrm{LOD}$ & $<\mathrm{LOD}$ & $<\mathrm{LOD}$ & $-0.47 \pm 0.15$ \\
\hline 100 & $<\mathrm{LOD}$ & $<\mathrm{LOD}$ & $<\mathrm{LOD}$ & $<\mathrm{LOD}$ & $<L O D$ & $-0.44 \pm 0.47$ \\
\hline 200 & $<L O D$ & $<\mathrm{LOD}$ & $<L O D$ & $<\mathrm{LOD}$ & $<L O D$ & $-0.30 \pm 0.41$ \\
\hline \multicolumn{7}{|l|}{ B } \\
\hline 0 & $-0.33 \pm 0.10$ & $-0.33 \pm 0.10$ & $-0.49 \pm 0.51$ & $-0.49 \pm 0.51$ & $-0.07 \pm 0.26$ & $-0.07 \pm 0.26$ \\
\hline 10 & $-0.55 \pm 0.13$ & $-0.41 \pm 0.26$ & $-0.39 \pm 0.11$ & $-0.16 \pm 0.06$ & $-0.51 \pm 0.16$ & $-0.32 \pm 0.32$ \\
\hline 20 & $-0.25 \pm 0.27$ & $0.37 \pm 0.05$ & $-0.27 \pm 0.22$ & $-0.37 \pm 0.12$ & $-0.68 \pm 0.49$ & $-0.28 \pm 0.23$ \\
\hline 50 & $0.32 \pm 0.26$ & $0.43 \pm 0.51$ & $-0.34 \pm 0.09$ & $-0.23 \pm 0.20$ & -1.60 & $-0.32 \pm 0.23$ \\
\hline 100 & $-0.54 \pm 0.01$ & $0.03 \pm 0.14$ & $-0.38 \pm 0.18$ & $0.35 \pm 0.24$ & $<L O D$ & $0.52 \pm 0.23$ \\
\hline 200 & $-0.36 \pm 0.13$ & $0.35 \pm 0.24$ & $-0.30 \pm 0.20$ & $-0.47 \pm 0.35$ & $<L O D$ & $-0.34 \pm 0.16$ \\
\hline \multicolumn{7}{|l|}{ C } \\
\hline 0 & $-0.33 \pm 0.10$ & $-0.33 \pm 0.10$ & $-0.49 \pm 0.51$ & $-0.49 \pm 0.51$ & $-0.07 \pm 0.26$ & $-0.07 \pm 0.26$ \\
\hline 10 & $-2.65 \pm 0.51$ & $-0.96 \pm 0.27$ & $-1.27 \pm 0.12$ & $-0.59 \pm 0.24$ & $-1.41 \pm 0.51$ & $-0.79 \pm 0.50$ \\
\hline 20 & $-2.27 \pm 0.46$ & $-1.08 \pm 0.48$ & $-1.33 \pm 0.13$ & $-0.07 \pm 0.50$ & $-1.48 \pm 0.55$ & $-0.64 \pm 0.66$ \\
\hline 50 & $-3.16 \pm 0.77$ & $-1.16 \pm 0.21$ & $-1.75 \pm 0.11$ & $-0.62 \pm 0.38$ & $-2.96 \pm 1.38$ & $-1.22 \pm 0.67$ \\
\hline 100 & $-2.47 \pm 0.37$ & $-1.56 \pm 0.33$ & $-2.20 \pm 0.50$ & $-1.01 \pm 0.11$ & $-3.58 \pm 0.65$ & $-2.06 \pm 1.63$ \\
\hline 200 & $-2.91 \pm 0.63$ & $-1.53 \pm 0.17$ & $-2.52 \pm 1.13$ & $-0.99 \pm 0.41$ & $-3.02 \pm 1.10$ & $-0.63 \pm 0.55$ \\
\hline
\end{tabular}

Quantification by RT-qPCR assays A of $10^{8}$ copies of the genome of viral RNA after monoazide treatment without photoactivation (A), after monoazide treatment without photoactivation followed by QIA-quick purification (B), after monoazide treatment with photoactivation followed by QIA-quick purification (C). Mean values $\pm S D(n=3)$.

With $20 \mu \mathrm{M}$ of PMA, an inhibitory effect on RT-qPCR was also found for HAV RNA $\left(-1.59 \log _{10}\right)$. PMA concentrations ranging from $50 \mu \mathrm{M}$ to $200 \mu \mathrm{M}$ were able to totally inhibit the RT-qPCR amplification of viral RNA. Inhibitory effects of EMA were found from $20 \mu \mathrm{M}$ on RV (Wa) $\left(-1.18 \log _{10}\right)$, and from $50 \mu \mathrm{M}$ on $\operatorname{HAV}(-0.99$ $\left.\log _{10}\right)$. Higher concentrations of EMA totally inhibited RT-qPCR assays on HAV and RV (Wa) viral RNA. Inversely, no inhibitory effect of any of the EMA concentrations tested was observed with RV (SA11) RNA. The efficacy of the purification of excess dye in treated RNA samples using the QIAquick PCR purification kit was tested to avoid inhibitory effects on RT-qPCR amplification (Table 1B). Purification by QIA-quick showed effective recovery with a decrease in viral titer $\leq-0.49 \log _{10}$ with RNA samples not treated with monoazide. The purification step was found to be effective in removing residual dye, except for RV (SA11) RNA samples which were treated with PMA ranging from 50 to $200 \mu \mathrm{M}$.

Lastly, optimal PMA / EMA concentrations were determined on viral RNA samples after dye treatment including photoactivation and purification steps. The effects of dye (concentrations of 10 to $200 \mu \mathrm{M}$ ) were determined by measuring the decrease in RNA quantification by RT-
qPCR (Table 1C). PMA at $50 \mu \mathrm{M}$ enabled the highest reduction of the RT-qPCR signal for HAV RNA (- 3.16 $\left.\log _{10}\right)$ and PMA at 100 and $200 \mu \mathrm{M}$ respectively enabled the highest reductions of the RT-qPCR signal for RV (SA11) $\left(-3.58 \log _{10}\right)$ and RV (Wa) $\left(-2.52 \log _{10}\right)$. EMA was still found to be less efficient than PMA treatment for all the viral RNA tested. These data showed that PMA and EMA are able to bind to viral RNA upon photoactivation making the RNA unavailable for amplification by RTqPCR, although excess dye concentrations can inhibit RT-qPCR assays. The effectiveness of PMA and EMA treatments depends on the type of dye, the concentration of the dye and the viral RNA type, although PMA was found to be the most effective dye for the three viral RNA tested.

Optimization of pretreatment combining dyes and surfactants before RT-qPCR assays for the selective detection of infectious viruses

Determination of optimal PMA / EMA concentrations

Table 2 shows the results of experiments conducted with viruses (HAV and RV (Wa, SA11)) to optimize a specific procedure based on dye treatment for selective detection of the viral RNA from infectious viruses using RT-qPCR assays A. 
Table 2 Influence of dye concentration on viruses

\begin{tabular}{|c|c|c|c|c|c|c|c|c|c|c|c|c|}
\hline \multirow{2}{*}{$\begin{array}{l}\text { Titration } \\
\text { method }\end{array}$} & \multirow[t]{2}{*}{ Virus } & \multirow{2}{*}{$\begin{array}{l}\text { Infectious / } \\
\text { inactived }\end{array}$} & \multicolumn{5}{|c|}{ PMA $(\mu \mathrm{M})$} & \multicolumn{5}{|c|}{ EMA $(\mu \mathrm{M})$} \\
\hline & & & 5 & 20 & 50 & 75 & 100 & 5 & 20 & 50 & 75 & 100 \\
\hline \multirow[t]{6}{*}{ RT-qPCR } & HAV & Infectious & $0.03 \pm 0.08$ & $0.02 \pm 0.08$ & $-0.03 \pm 0.02$ & $-0.08 \pm 0.01$ & $-0.02 \pm 0.05$ & $-0.10 \pm 0.17$ & $-0.04 \pm 0.02$ & $-0.07 \pm 0.07$ & $-0.05 \pm 0.05$ & $-0.09 \pm 0.03$ \\
\hline & & Inactived & $-0.88 \pm 0.12$ & $-1.01 \pm 0.08$ & $-1.06 \pm 0.11$ & $-1.13 \pm 0.09$ & $-1.14 \pm 0.09$ & $-1.24 \pm 0.13$ & $-1.75 \pm 0.91$ & $-1.31 \pm 0.28$ & $-1.25 \pm 0.24$ & $-1.17 \pm 0.23$ \\
\hline & RV (SA11) & Infectious & $-0.28 \pm 0.38$ & $-0.32 \pm 0.44$ & $-0.30 \pm 0.33$ & $-0.68 \pm 0.41$ & $-0.51 \pm 0.28$ & $-0.70 \pm 0.12$ & $-0.70 \pm 0.30$ & $-0.71 \pm 0.08$ & $-0.75 \pm 0.09$ & $-0.72 \pm 0.09$ \\
\hline & & Inactived & $-1.16 \pm 0.68$ & $-1.45 \pm 0.78$ & $-1.60 \pm 0.57$ & $-1.70 \pm 0.40$ & $-1.71 \pm 0.50$ & $-1.12 \pm 0.31$ & $-1.13 \pm 0.19$ & $-1.05 \pm 0.33$ & $-1.06 \pm 0.24$ & $-1.07 \pm 0.07$ \\
\hline & RV (Wa) & Infectious & $0.05 \pm 0.09$ & $-0.38 \pm 0.34$ & $-0.63 \pm 0.02$ & $-0.62 \pm 0.14$ & $-0.52 \pm 0.15$ & $-0.19 \pm 0.05$ & $-0.50 \pm 0.20$ & $-0.96 \pm 0.31$ & $-1.12 \pm 0.16$ & $-1.15 \pm 0.13$ \\
\hline & & Inactived & $-0.24 \pm 0.65$ & $-0.62 \pm 0.27$ & $-1.00 \pm 0.15$ & $-1.44 \pm 0.18$ & $-1.45 \pm 0.29$ & $-0.52 \pm 0.76$ & $-1.51 \pm 0.26$ & $-1.81 \pm 0.06$ & $-1.72 \pm 0.19$ & $-1.48 \pm 0.18$ \\
\hline
\end{tabular}


As the first step in exploring the potential of PMA and EMA to detect infectious viruses, HAV, RV (SA11) and RV (Wa) viruses were either inactivated thermally or not, and were subjected to dye concentrations ranged from 5 to $100 \mu \mathrm{M}$, photoactivation, RNA extraction and quantification by RT-qPCR (Table 2). The presence of PMA or EMA had no effect on detection of the RNA extracted from infectious HAV regardless of the concentration tested. Similarly, quantification of RNA extracted from PMA-treated infectious RV was not strongly affected by decreases ranging from $-0.05 \log _{10}$ to $-0.63 \log _{10}$ for Wa and from - $0.28 \log _{10}$ to $-0.68 \log _{10}$ for SA11, depending on the PMA concentrations tested. However, quantification of RNA extracted from infectious RV was more strongly affected by EMA treatment, with a decrease between - $0.19 \log _{10}$ and - $1.15 \log _{10}$ for Wa and between $0.70 \log _{10}$ and $-0.75 \log _{10}$ for SA11, depending on the EMA concentrations tested.

When thermally inactivated viruses were assayed with PMA RT-qPCR, maximum decreases were found for HAV (- $1.06 \log _{10}$ to $\left.-1.14 \log _{10}\right)$ and for RV (SA11) $(-1.60$ $\log _{10}$ to $\left.-1.71 \log _{10}\right)$ with PMA concentrations ranging from $50 \mu \mathrm{M}$ to $100 \mu \mathrm{M}$, and for RV (Wa) $\left(-1.44 \log _{10}\right.$ and - $1.45 \log _{10}$ ) with PMA concentrations of $75 \mu \mathrm{M}$ and $100 \mu \mathrm{M}$. When inactivated viruses were assayed with EMA RT-qPCR, maximum decreases were found for HAV $\left(-1.75 \log _{10}\right)$ with EMA at $20 \mu \mathrm{M}$, for RV (SA11) $\left(-1.13 \log _{10}\right)$ with EMA at $20 \mu \mathrm{M}$, and for RV (Wa) $\left(-1.81 \log _{10}\right)$ with EMA at $50 \mu \mathrm{M}$.

The data obtained with all the negative controls were as expected. Treatment by PMA / EMA without photoactivation or with a single exposure of the viruses to light before RNA extraction did not significantly affect the RT-qPCR detection of extracted RNA (data not shown).

The most effective dye concentration for each virus was experimentally chosen by taking into account the effect of the dye concentrations on the inactivated and infectious viruses. In cases where similar data were observed with different dye concentrations, the lowest dye concentration was preferred. Thus, $20 \mu \mathrm{M}$ of EMA for all viruses, $50 \mu \mathrm{M}$ of PMA for HAV and RV (SA11) and $75 \mu \mathrm{M}$ of PMA for RV (Wa) were selected as optimal concentrations.

Evaluation of pre-treatments combining dye and surfactant As a second step, Triton X-100, Tween 20 and IGEPAL CA-630, three widely used nonionic surfactants, were tested for their efficacy in improving the effects of PMA / EMA treatment on viral particles (Table 3).

Beforehand, we attempted to evaluate surfactant toxicity towards the infectivity of HAV and rotavirus strains, which would preclude their use as a discriminatory treatment. One set of HAV viral samples receiving surfactants was compared to untreated HAV viral samples by titration with cell culture. None of the surfactant treatments significantly reduced the initial HAV titer $\left(\leq 0.20 \log _{10}\right)$, which argues in favor of the use of a dyesurfactant pre-treatment. It was not possible to measure the toxicity of surfactants to RV strains (Wa and SA11) because all surfactant doses affected the MA104 cells in culture (data not shown).

The previously selected optimal dye concentration for each virus $(20 \mu \mathrm{M}$ of EMA for all viruses, $50 \mu \mathrm{M}$ of PMA for HAV and RV (SA11) and $75 \mu \mathrm{M}$ of PMA for RV (Wa)) were tested in association with three concentrations of three surfactants.

When inactivated HAV was assayed, Tween 20 only very slightly increased the efficacy of PMA $(50 \mu \mathrm{M})$ $\left(<-0.7 \log _{10}\right)$ and did not increase the efficacy of EMA $(20 \mu \mathrm{M})$ pretreatments. The pretreatments of inactivated HAV associating PMA $(50 \mu \mathrm{M})$ with IGEPAL CA-630 or Triton $\times 100$ improved the processing regardless of the concentration of surfactant tested. Indeed, the logarithmic reductions of RNA detected by RT-qPCR were included between - $2.34 \log _{10}$ and - $2.49 \log _{10}$ which was higher than the reduction of $1.06 \log _{10}$ obtained with PMA treatment at $50 \mu \mathrm{M}$. Similarly, the processing of inactivated HAV associating EMA $(20 \mu \mathrm{M})$ with IGEPAL CA-630 or Triton $\times 100$, regardless of the concentration of surfactant tested, enhanced the efficacy of the processing. Indeed, the logarithmic reductions of RNA detected by RT-qPCR were included between - 2.23 $\log _{10}$ and $-2.68 \log _{10}$ which was higher than the reduction of $1.75 \log _{10}$ obtained with EMA treatment at $20 \mu \mathrm{M}$. Finally, the treatment of HAV by the most promising IGEPAL CA-630 (0.5\%) without monoazide or photoactivation before RNA extraction did not affect RT-qPCR detection of extracted RNA, which argues in favor of the use of a dye-surfactant pre-treatment (data not shown).

When inactivated RV (SA11) was assayed, the efficacy of the processing with PMA $(50 \mu \mathrm{M})$ was always slightly higher without surfactant. When inactivated RV (SA-11) was assayed with EMA and surfactants, the highest improvement was found with Tween $20(0.5 \%)$ leading to an increase of reduction of RNA detected by RT-qPCR of $-0.76 \log _{10}$ compared with treatment with EMA at $20 \mu \mathrm{M}$. However, the pre-treatment based on EMA also seemed to affect RNA detection from infectious RV (SA11) $\left(-0.72 \log _{10}\right)$ more than the pre-treatment based on PMA $\left(-0.30 \log _{10}\right)$. When inactivated RV (Wa) was assayed, none of the tested surfactants increased the efficacy of the dye pretreatments.

By taking into account all these data, we selected pretreatments with EMA $(20 \mu \mathrm{M})$ and IGEPAL CA-630 (0.5\%) for HAV, with EMA $(20 \mu \mathrm{M})$ for RV (Wa) and PMA $(50 \mu \mathrm{M})$ for RV (SA11) for their high efficiencies. Since different incubation times (30 min, $2 \mathrm{~h}$, overnight) 
Table 3 Influence of combined dyes and surfactants on viruses

\begin{tabular}{|c|c|c|c|c|c|c|c|c|c|c|c|c|}
\hline \multirow{2}{*}{$\begin{array}{l}\text { Titration } \\
\text { method }\end{array}$} & \multirow[t]{2}{*}{ Virus } & \multirow{2}{*}{$\begin{array}{c}\text { Infectious / } \\
\text { inactived }\end{array}$} & \multirow[t]{2}{*}{ Dye } & \multicolumn{3}{|c|}{ Triton $\times 100$} & \multicolumn{3}{|c|}{ Tween 20} & \multicolumn{3}{|c|}{ IGEPAL CA-630 } \\
\hline & & & & $0.1 \%$ & $0.5 \%$ & $1 \%$ & $0.1 \%$ & $0.5 \%$ & $1 \%$ & $0.1 \%$ & $0.5 \%$ & $1 \%$ \\
\hline \multirow{12}{*}{ RT-qPCR } & \multirow[t]{4}{*}{ HAV } & Infectious & EMA $(20 \mu \mathrm{M})$ & $0.03 \pm 0.07$ & $-0.06 \pm 0.06$ & $-0.05 \pm 0.05$ & $-0.02 \pm 0.09$ & $-0.07 \pm 0.09$ & $-0.02 \pm 0.06$ & $0.02 \pm 0.13$ & $-0.02 \pm 0.05$ & $-0.04 \pm 0.09$ \\
\hline & & Inactived & & $-2.42 \pm 0.04$ & $-2.52 \pm 0.10$ & $-2.48 \pm 0.01$ & $-1.70 \pm 0.05$ & $-1.88 \pm 0.29$ & $-1.89 \pm 0.08$ & $-2.23 \pm 0.41$ & $-2.68 \pm 0.01$ & $-2.42 \pm 0.07$ \\
\hline & & Infectious & PMA $(50 \mu M)$ & $-0.07 \pm 0.02$ & $-0.07 \pm 0.02$ & $0.00 \pm 0.02$ & $-0.05 \pm 0.06$ & $-0.12 \pm 0.07$ & $-0.09 \pm 0.09$ & $-0.06 \pm 0.08$ & $-0.04 \pm 0.05$ & $-0.07 \pm 0.10$ \\
\hline & & Inactived & & $-2.34 \pm 0.27$ & $-2.49 \pm 0.25$ & $-2.51 \pm 0.23$ & $-1.74 \pm 0.07$ & $-1.70 \pm 0.09$ & $-1.70 \pm 0.11$ & $-2.42 \pm 0.27$ & $-2.49 \pm 0.34$ & $-2.34 \pm 0.19$ \\
\hline & \multirow[t]{4}{*}{$\mathrm{RV}(\mathrm{SA} 11)$} & Infectious & EMA $(20 \mu \mathrm{M})$ & $-0.80 \pm 0.10$ & $-0.77 \pm 0.08$ & $0.47 \pm 0.11$ & $0.75 \pm 0.14$ & $-0.72 \pm 0.07$ & $-0.68 \pm 0.09$ & $-0.79 \pm 0.07$ & $-0.47 \pm 0.09$ & $-0.71 \pm 0.09$ \\
\hline & & Inactived & & $-1.66 \pm 0.09$ & $1.43 \pm 0.15$ & $-1.14 \pm 0.28$ & $-1.18 \pm 0.17$ & $-1.89 \pm 0.77$ & $-1.28 \pm 0.20$ & $-1.30 \pm 0.13$ & $-1.28 \pm 0.30$ & $-0.81 \pm 0.27$ \\
\hline & & Infectious & PMA $(50 \mu M)$ & $-0.74 \pm 0.15$ & $-0.77 \pm 0.16$ & $-0.91 \pm 0.20$ & $0.80 \pm 0.11$ & $-0.76 \pm 0.20$ & $-0.80 \pm 0.20$ & $-0.72 \pm 0.14$ & $0.71 \pm 0.23$ & $-0.81 \pm 0.18$ \\
\hline & & Inactived & & $-1.34 \pm 0.18$ & $-1.29 \pm 0.13$ & $-1.33 \pm 0.22$ & $-1.30 \pm 0.15$ & $-1.39 \pm 0.16$ & $-1.31 \pm 0.49$ & $-1.31 \pm 0.27$ & $-1.35 \pm 0.25$ & $-1.14 \pm 0.39$ \\
\hline & \multirow[t]{4}{*}{ RV (Wa) } & Infectious & EMA $(20 \mu \mathrm{M})$ & $-0.39 \pm 0.07$ & $-0.24 \pm 0.13$ & $-0.15 \pm 0.10$ & $-0.41 \pm 0.06$ & $-0.13 \pm 0.13$ & $-0.37 \pm 0.17$ & $-0.28 \pm 0.22$ & $-0.21 \pm 0.02$ & $0.36 \pm 0.13$ \\
\hline & & Inactived & & $-1.21 \pm 0.14$ & $-0.68 \pm 0.12$ & $-0.40 \pm 0.16$ & $-1.01 \pm 0.19$ & $-0.88 \pm 0.15$ & $-0.58 \pm 0.16$ & $-0.82 \pm 0.43$ & $-0.71 \pm 0.08$ & $-0.14 \pm 0.13$ \\
\hline & & Infectious & PMA $(75 \mu \mathrm{M})$ & $-0.57 \pm 0.14$ & $-0.61 \pm 0.18$ & $-0.61 \pm 0.13$ & $-0.58 \pm 0.15$ & $-0.58 \pm 0.11$ & $-0.64 \pm 0.14$ & $-0.60 \pm 0.16$ & $-0.58 \pm 0.15$ & $-0.70 \pm 0.16$ \\
\hline & & Inactived & & $-1.23 \pm 0.08$ & $-1.11 \pm 0.04$ & $-1.20 \pm 0.18$ & $-1.21 \pm 0.08$ & $-1.15 \pm 0.09$ & $-1.15 \pm 0.17$ & $-1.21 \pm 0.08$ & $-1.15 \pm 0.18$ & $-1.23 \pm 0.08$ \\
\hline Cell culture & HAV & Infectious & None & $0.09 \pm 0.22$ & $-0.03 \pm 0.17$ & $0.02 \pm 0.21$ & $0.11 \pm 0.11$ & $0.16 \pm 0.06$ & $0.04 \pm 0.25$ & $0.06 \pm 0.17$ & $-0.01 \pm 0.01$ & $0.14 \pm 0.09$ \\
\hline
\end{tabular}

Quantification by RT-qPCR assays A after monoazide treatment combined with surfactants (Triton $\times 100$, Tween-20, IGEPAL CA-630) of $10^{5} \mathrm{TCID}_{50}$ of RV (SA11), 10 $0^{3}$ TCID $D_{50}$ of RV (Wa) and $6 \times 10^{4}$ PFU of HAV, infectious or inactivated at $80^{\circ} \mathrm{C}$ for 10 minutes, and titration by cell culture of $6 \times 10^{4} \mathrm{PFU}$ of infectious HAV treated with surfactants. Mean values \pm SD $(n=3)$. 
did not change the selected pre-treatment efficiencies (data not shown), an incubation time of $2 \mathrm{~h}$ was selected for the following studies.

\section{Kinetic thermal viral inactivation curves and impact of RT- qPCR assays}

The heat sensitivity of HAV and RV (Wa, SA11) at four temperatures $\left(37^{\circ} \mathrm{C}, 68^{\circ} \mathrm{C}, 72^{\circ} \mathrm{C}, 80^{\circ} \mathrm{C}\right)$ was analyzed by kinetic evaluation of the loss of infectivity in cell culture compared with the loss of genomic titer in RT-qPCR assays with or without pre-treatment. Stable secondary structures may facilitate the covalent binding of PMA / EMA to viral RNA rendering the RNA undetectable by RT-qPCR. Moreover, amplicon length may influence the effectiveness of these assays. Three RT-qPCR assays were assayed for each viral target to explore the impact of the amplified genomic region on the success of the pre-treatment-RT-qPCR assays in detecting the infectious viruses. The $\log _{10}$ reduction detection limits of the cell culture technique were $-4 \log _{10}$ PFU of HAV, -5.5 $\log _{10} \mathrm{TCID}_{50}$ of RV (Wa) and $-3.5 \log _{10} \mathrm{TCID}_{50}$ of RV (SA11). For describing all the inactivation curves, the log-linear + tail model was found to be the most appropriate. Figures 1 and 2 show the values of the parameters of Equation (2) that characterized the fate of the HAV and RV strain levels respectively according to the four different temperatures, and to the three methods of quantification of the virus titer, i.e. RT-qPCR and pretreatment RT-qPCR depending on the three different RT-qPCR assays used and the infectious titer.

For HAV, the values of $\mathrm{S}_{\mathrm{i}, 0}$ were not different from zero, which means that the EMA IGEPAL CA-630 treatment did not affect virus quantification with regard to the RT-qPCR method. At $37^{\circ} \mathrm{C}$, the level of HAV remained constant regardless of the method used. For other temperatures, $k_{\max }$, which is the inactivation rate, increased with temperature. Using a Bigelow-type model, relating $D$-value to temperature, this increase corresponds to z-values ranging from $17^{\circ} \mathrm{C}$ to $22^{\circ} \mathrm{C}$ for EMA-IGEPAL CA-630 -RTqPCR and infectious titration methods and of $44^{\circ} \mathrm{C}$ for the RT-qPCR method, regardless of the RT-qPCR assay. Confidence intervals of $S_{\mathrm{i}, \text { res }}$ indicate that the fraction of virus that can survive thermal treatment differs depending on the titration method used and the temperature. With EMA-IGEPAL CA-630 - RT-qPCR and RT-qPCR assay C, the $S_{2 \text {,res }}$ value is approximately $-1.6 \log _{10}$, which means that 1 virus out of 40 is quantifiable after 20 min of treatment regardless of the temperature. With EMA-IGEPAL CA-630 - RT-qPCR and RT-qPCR assay A or B, between 1 virus out 200 and 1 virus out of 6000 is still quantifiable after treatment at $68^{\circ} \mathrm{C}$ and $80^{\circ} \mathrm{C}$ (with $S_{2, \text { res }}$ ranged between $-2.3 \log _{10}$ and $\left.-3.8 \log _{10}\right)$. For RT-qPCR, $S_{1 \text {,res }}$ are much higher than $S_{2, \text { res }}$, but the difference between RTqPCR assays $\mathrm{A}$ and $\mathrm{B}$ and RT-qPCR assay $\mathrm{C}$ was also observed for RT-qPCR. For the infectious titration method, $S_{3, \text { res }}$ is around $-3.5 \log _{10}$, close to the values obtained with EMA-IGEPAL CA-630 - RT-qPCR associated with RTqPCR assays $A$ and $B$.

For RV strains, the values of $S_{2,0}$ were lower than zero, which means that the EMA / PMA treatment affected virus quantification with regard to the RT-qPCR method. Indeed, the reduction of the concentration of infectious virus due to the monoazide pre-treatment was about of $-0.5 \log _{10}$ by using RT-qPCR assay $\mathrm{A}$ and is ranged from $-1.2 \log _{10}$ to $-2.5 \log _{10}$ by using RT-qPCR assays B and C. These reduction levels were the same for both RV strains. At $37^{\circ} \mathrm{C}$, the level of RV strains remained constant regardless of the method used. At $68^{\circ} \mathrm{C}, 72^{\circ} \mathrm{C}$, and $80^{\circ} \mathrm{C}$, the genomic titer of the RV strains was found to be constant by using the RTqPCR method regardless of the RT-qPCR assay tested. The $S_{\mathrm{i} \text {,es }}$ confidence intervals indicate that the fraction of virus that can survive thermal treatment differs depending on the titration method used.

For the Wa RV strain, with EMA-RT-qPCR and RTqPCR assay A, the $S_{2 \text {,res }}$ value was approximately -1.3 $\log _{10}$ which means 1 virus out of 20 was quantifiable after 20 min of treatment regardless of the temperature. With EMA-RT-qPCR and RT-qPCR assays B or C, between 1 virus out of $10^{4}$ and 1 virus out of $10^{5}$, was still quantifiable after treatment at $68^{\circ} \mathrm{C}, 72^{\circ} \mathrm{C}$ or $80^{\circ} \mathrm{C}$ (i.e. $S_{2, \text { res }}$ ranged between $-4 \log _{10}$ and $\left.-5 \log _{10}\right)$. The $S_{3, \text { res }}$ values obtained with the infectious titration method were similar to the $S_{2, \text { res }}$ values of RT-qPCR assays B and $\mathrm{C}$.

For the SA11 RV strain, with PMA-RT-qPCR and RTqPCR assay A, $S_{2 \text {,res }}$ value is approximately $-1.2 \log _{10}$. With RT-qPCR assays B and C, $S_{2 \text {,res }}$ ranged from -2.4 $\log _{10}$ and $-3.9 \log _{10}$. The value of $S_{2 \text {,res }}$ with these RTqPCR assays decreased significantly when the temperature of treatment increases. $S_{3, \text { res }}$ values cannot be estimated as inactivation after 1 minute of treatment for $68^{\circ} \mathrm{C}, 72^{\circ} \mathrm{C}$ or $80^{\circ} \mathrm{C}$ was higher than the LOQ.

For SA11, the $k_{\max }$ value increased with the temperature. Using a Bigelow-type model, this increase corresponds to z-values ranging from $15^{\circ} \mathrm{C}$ to $19^{\circ} \mathrm{C}$ according to the RTqPCR assays for the PMA-RT-qPCR method and of $28^{\circ} \mathrm{C}$ for the infectious titration method. For the Wa strain and EMA-RT-qPCR, the large confidence interval observed for $k_{\max }$ did not make it possible to detect a temperature effect. Very fast inactivation of Wa strain, (after 1 minute of treatment, infectious titers were below the limit of detection (LOD)) only allows to argue that $k_{\max }$ values were higher than 8.

In conclusion, assays conducted to examine the efficiency of pre-treatment RT-qPCR in minimizing detection signals from thermally-inactivated viruses were dependent on virus species, on the temperature of inactivation and on the RT-qPCR assays. 

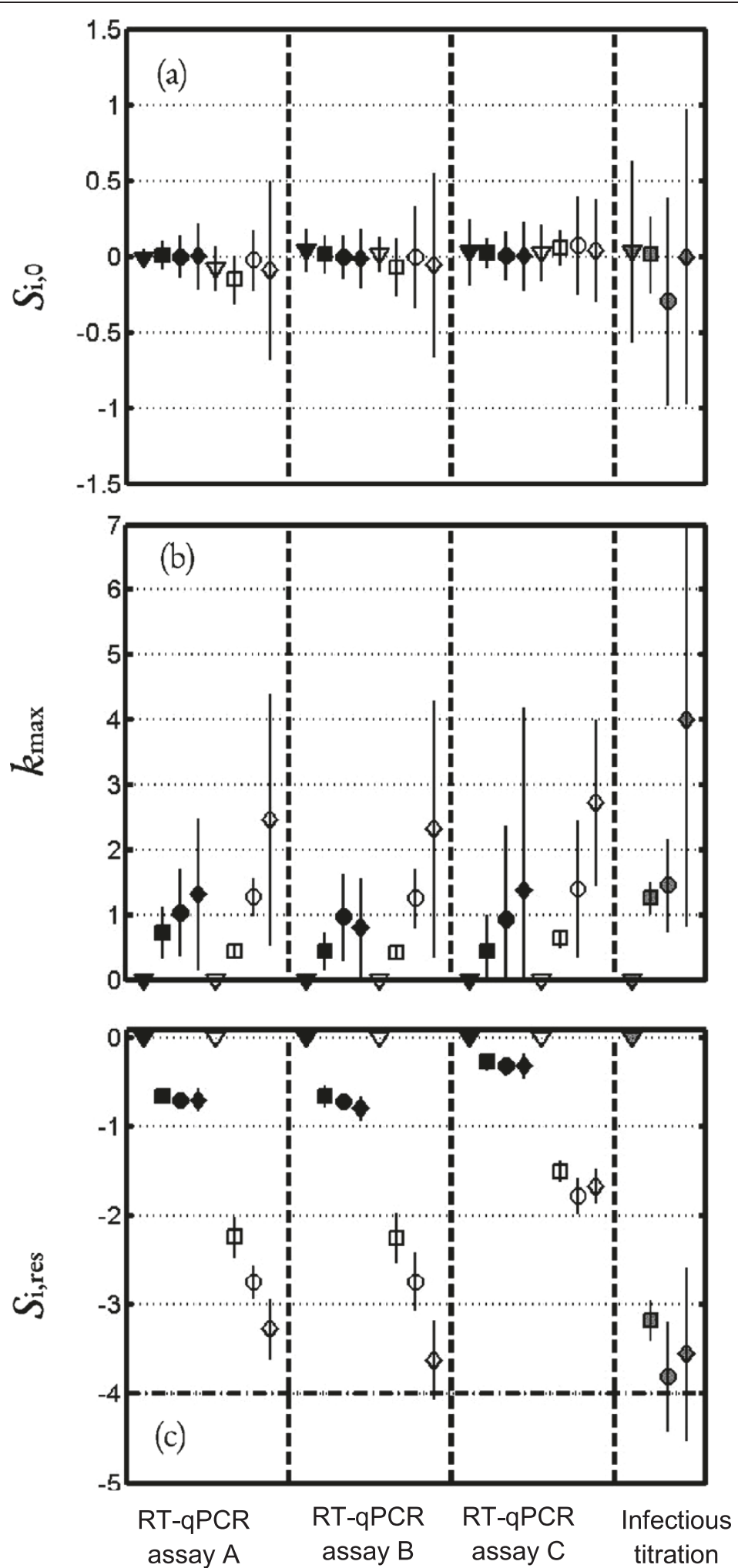

Figure 1 Thermal inactivation kinetics of HAV. Thermal Inactivation kinetics of HAV $(\mathbf{a}, \mathbf{b}, \mathbf{c})$, expressed with the log-linear + tail model: $\log _{10}\left(S_{i}(t)\right)=$ $\log _{10}\left(\left(S_{i, 0}-S_{i, r e s}\right) \cdot \exp \left(-k_{\max } \cdot t\right)+S_{i, r e s}\right)$ (Equation 2). Plots of the estimated parameters for Equation 2 and the corresponding $95 \%$ asymptotic confidence intervals for HAV. (a) $\mathrm{S}_{i, 0}$; (b) $k_{\text {maxi }}$ (c) $\mathrm{S}_{\text {i,res }}$. The results obtained at $37^{\circ} \mathrm{C}, 68^{\circ} \mathrm{C}, 72^{\circ} \mathrm{C}$ and $80^{\circ} \mathrm{C}$ are indicated by $\boldsymbol{\nabla}, \mathbf{m}, \bullet$ and $\bullet$ respectively. Symbol shaded in gray indicates data obtained with cell culture method, symbol in black indicates RT-qPCR and open symbol represents RT-qPCR with pre-treatment (- - ) Limit of quantification. 


\section{Discussion and conclusion}

Foodborne viruses have emerged as a major cause of outbreaks worldwide. Among the factors that affect virus survival, temperature has a great influence on virus stability in food as in any other matrix. Therefore, food industries widely apply temperature as a virus-inactivating factor. Natural or added constituents of food and the virus species may influence the rate of virus inactivation by temperature but higher temperatures provided more pronounced virus decay [24]. The primary model that was found to effectively describe thermal virus inactivation in our study, (i.e. the log-linear + tail primary inactivation model), was similar to the one chosen to describe thermal inactivation of HAV in raspberries [25]. The infectivity of enteric viruses requires the functional integrity of two major components, the capsid and the genome [26]. While quantitative RT-PCR is a specific and sensitive tool for determining the quantities of viral genomes in the environment and food samples, it does not discriminate between infectious viruses and noninfectious viruses that do not pose a threat to health. Moreover, the virus genome was shown to be more resistant than the infectious virus. So, methods which provide information about the infectivity are particularly useful for the detection of enteric viruses and would be an advantage in a public health perspective [27].

Recently, ethidium monoazide (EMA) and propidium monoazide (PMA), which are intercalating dyes, have been used combined with PCR or real-time PCR for the selective detection of viable microorganisms. In this study, monoazides were tested in association with surfactants in order to develop a technique for determining the residual infectivity of thermally inactivated enteric viruses. These assays are based on the penetration of monoazide, potentially facilitated by the action of surfactants, through damaged or compromised capsids and its covalent binding to viral RNA, which makes the genome unavailable for amplification by RT-qPCR.

In this study, it was hypothesized that the PMA / EMA would be able to enter non-infectious RV / HAV viruses and easily bind to the dsRNA of RV and to the highly structured 5'-non coding region (5'-NCR) of HAV ssRNA targeted by the RT-qPCR assays [28]. The pretreatment RT-qPCR assays with the shortest amplification fragments for RV (87-bp) and HAV (77-bp) did not produce data similar to those obtained by measuring the decrease in the number of infectious particles following heat treatment. By using both longer amplification fragments (313-bp; 352-bp) targeting two different regions of RV dsRNA, data obtained with pretreatment RTqPCR were very similar suggesting that the targeted region had not influenced the success of the pretreatment RT-qPCR for dsRNA. Similarly, both longer amplification regions for HAV ssRNA (174-bp; 353-bp) provided data suggesting that the stable secondary structures may facilitate covalent binding of monoazide to HAV ssRNA. Thus, the stable secondary structures may facilitate covalent binding of monoazide to viral RNA, rendering the RNA undetectable by RT-qPCR. Besides the targeted genome region, this study also showed the influence of the RT-qPCR assays in terms of length of amplicons for three viruses. Other studies have shown the influence of amplification length on the degree of PCR suppression by monoazide treatment in dead cells [29-31].

The HAV capsid is composed of the structural proteins VP1, VP2, VP3, and possibly VP4, encoded in the $\mathrm{P} 1$ region of the genome [32]. Cell culture-derived rotavirus preparations contain a mixture of double-layered particles (DLPs) and triple-layered particles (TLPs). The innermost layer of the rotavirus particle is made up of the core protein VP2, the middle layer is composed entirely of VP6, and the outermost layer of RV is composed of two proteins, VP4 and VP7 [33]. VP4 forms spikes that extend outwards from the surface of the virus and which have been linked to a variety of functions, including initial attachment of the virus to the cell membrane and penetration into the cell by the virion [34]. Indeed, the capsids structures may explain the differences of efficacy of thermal inactivation and of the penetration of monoazide. The presence of monoazide did not affect the measurement of HAV, but it slightly affected the measurement of both rotavirus strains. This effect appeared to be variable (between $0.5 \log _{10}$ and 2.5 $\log _{10}$ ) depending on the RT-qPCR assays and therefore not always an impediment to the use of monoazide pretreatment for RV. Nevertheless, this monoazide effect seems to be dependent on the virus type and should be evaluated to develop this approach with other viruses.

There is still very little development of monoazide RTqPCR methods for determining the infectiosity of enteric viruses. Among the few studies reported in the literature, Sánchez et al. [23] found that PMA treatment at $50 \mu \mathrm{M}$ was significantly more effective than RNase treatment for differentiating infectious and thermally-inactivated HAV $\left(99^{\circ} \mathrm{C}\right.$ for $\left.5 \mathrm{~min}\right)$, with HAV titers reduced by more than $2.4 \log _{10}$. The EMA - IGEPAL CA-630 - RT-qPCR assay developed in this study was significantly more effective for differentiating infectious and thermallyinactivated HAV with HAV titers reduced by more than $3 \log _{10}$ and $3.8 \log _{10}$ respectively with the RT-qPCR assays $\mathrm{A}$ and $\mathrm{B}$ after $5 \mathrm{~min}$ at $80^{\circ} \mathrm{C}$. $\mathrm{Z}$ values observed in the present study when infectious titration or pretreatmentRT-qPCR methods were used are consistent with those observed in the meta-analysis of inactivation of enteric viruses in food and water carried out by Bertrand et al. [24]. Nevertheless, when high inactivation temperatures were applied, clearer discriminations between infectious and non-infectious viruses were consistently observed with 


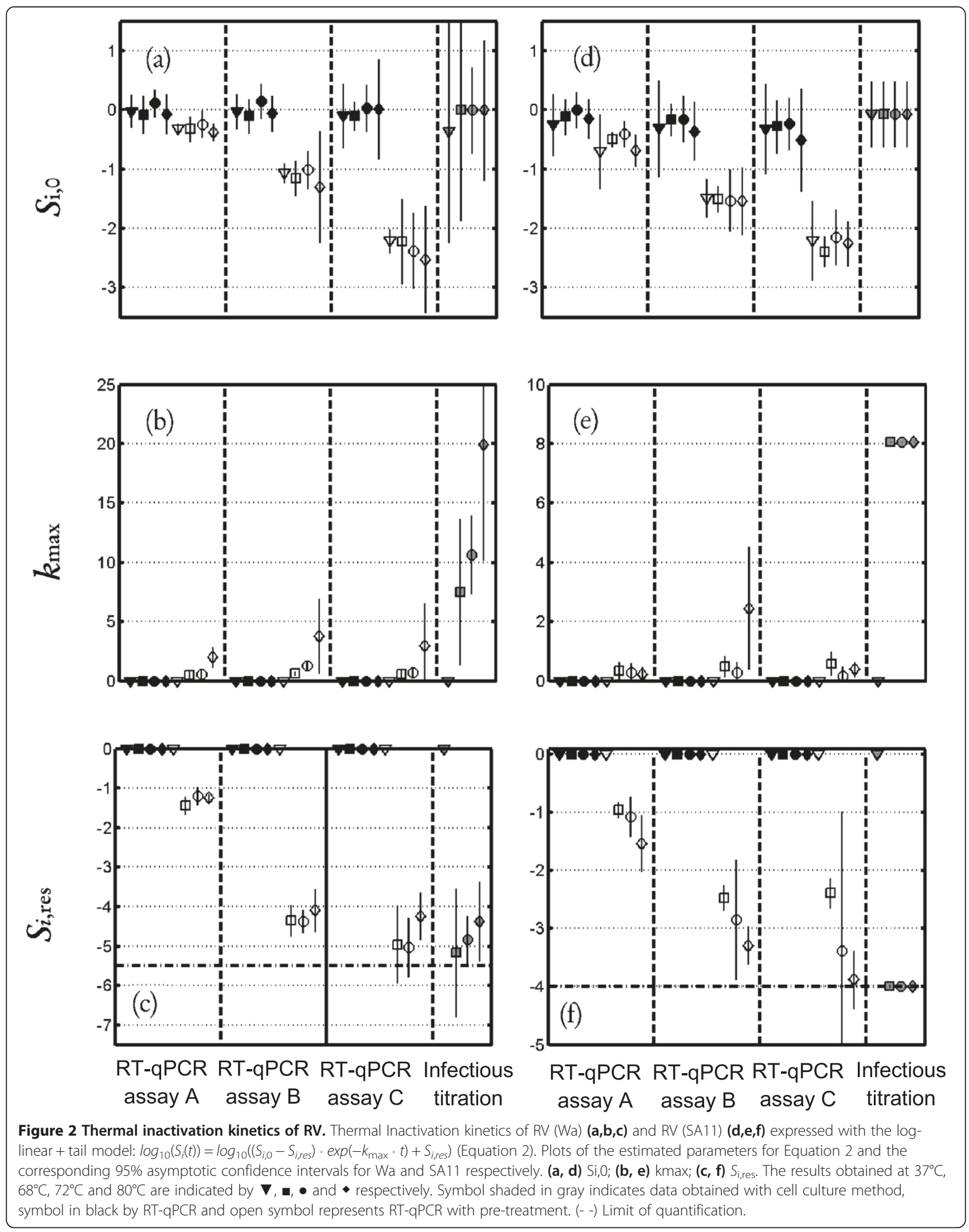


pre-treatment-RT-qPCR assays. Thus, the procedures reported in the present study provide limits that are comparable to those determined by others $[19,20,22]$. As the pre-enzymatic treatment-PCR approach, monoazide RTqPCR depend mainly on capsid integrity as the criterion for infectivity, and this could be one of the drawbacks of this technique since virus inactivation may take place by other means than particle disruption [9].

Optimization of EMA or PMA concentration and the choice of the RT-qPCR assay, as well as the addition of a complementary treatment to enhance the penetration of monoazide into the slightly-damaged capsid may lead to more effective monoazide treatment. This study showed that surfactants may be useful to improve monoazideRT-qPCR assays for HAV but not for RV.

In conclusion, the lack of information about infectious risk makes it necessary to evaluate new means of preventing a positive RT-qPCR signal in the absence of infectious virus. The pre-treatment of enteric viruses with monoazide alone or in conjunction with other capsiddisrupting aids prior to RT-qPCR may be optimized to obtain rapid differentiation between infectious and noninfectious viruses. This approach can potentially be used with all non-culturable and difficult to culture viruses but must be estimated with regard to the specific conditions of inactivation. Currently, it seems relevant to develop this approach for the identification of infectious viruses in food and environmental samples. However the potential multiple sources of inactivation, such as UVs, storing conditions, temperature, etc., could lead to changes in capsid protein conformation without compromising capsid integrity [9]. This is why it may be necessary to adapt and evaluate the dye treatment according to the inactivation type. Moreover, the efficacy of pre-treatment RT-qPCR assays could be affected by the types of samples (various food and environmental samples) and should be characterized in order to be developed further. Therefore, this new approach could be very useful for evaluating the susceptibility of non-culturable enteric viruses (e.g. norovirus, HAV, HEV) to specific inactivation / disinfection techniques or food processing strategies and could be an alternative to studies using culturable surrogate viruses that differ in structure, function and comportment.

\section{Methods}

\section{Viruses and cells}

HAV strain HM175/18f, clone B (VR-1402) was obtained from the American Type Culture Collection (ATCC). This clone replicates rapidly and has cytopathic effects in cell culture [35]. HAV stock was produced by propagation in foetal rhesus monkey kidney (FRhK-4) cells (ATCC, CRL1688) [36] and titrated by plaque assay [37]. Results were expressed in plaque-forming units $/ \mathrm{mL}(\mathrm{PFU} / \mathrm{mL})$ and HAV stock contained $10^{7} \mathrm{PFU} / \mathrm{mL}$.
Rotavirus strains SA11 (simian rotavirus A) and Wa (human rotavirus) were obtained from the Pasteur Institute (Paris, France) and were propagated in MA-104 rhesus monkey epithelial cell line (ATCC CRL-2378). MA-104 cells were grown in Minimum Essential Medium Glutamax $^{\text {Tix }}$ (MEM), 1\% non-essential amino acids, 10\% foetal bovine serum and $0.5 \%$ penicillin-streptomycin (Life Technologies, France). Cells were incubated at $37^{\circ} \mathrm{C}$ in an atmosphere containing 5\% $\mathrm{CO}_{2}$ and grown to subconfluence. Rotavirus viral stock solutions consisted of an infected cell culture supernatant. Infected cells were frozen and thawed once and then clarified using low-speed centrifugation $(6000 \times \mathrm{g})$ at $4^{\circ} \mathrm{C}$ to remove residual debris. The supernatant of SA11 contained $10^{7} \mathrm{TCID}_{50} / \mathrm{mL}$. The supernatant containing Wa was then ultracentrifugated at $151,000 \times \mathrm{g}$ for $1 \mathrm{~h}$ at $4^{\circ} \mathrm{C}$ to obtain a higher viral titer. The pellet was resuspended in PBS to obtain a Wa stock containing $10^{5} \mathrm{TCID}_{50} / \mathrm{mL}$. Both virus stocks were divided into aliquots and stored at $-80^{\circ} \mathrm{C}$. For the infectivity assay, sub-confluent MA-104 cells seeded in 96-well plates were washed twice with MEM. Samples were trypsinactivated for $30 \mathrm{~min}$ at $37^{\circ} \mathrm{C}$, and then added to MA-104 cells. Plates were incubated 3 days at $37^{\circ} \mathrm{C}$. Infectious titers of RV were expressed as $\mathrm{TCID}_{50} / \mathrm{mL}$, according to the Kärber method.

\section{RNA purification of Rotaviruses and HAV}

HAV and RV RNA stocks were produced from infected cell culture supernatants. They were centrifugated at $4,000 \mathrm{~g}$ for 30 minutes at $4^{\circ} \mathrm{C}$ and then the supernatants were ultracentrifugated at $25,000 \mathrm{~g}$ for $25 \mathrm{~min}$ at $4^{\circ} \mathrm{C}$. Finally, supernatants were ultracentrifugated at 151,000 g for $50 \mathrm{~min}$ at $4{ }^{\circ} \mathrm{C}$ and the pellets were suspended in aliquots of $0.7 \mathrm{~mL}$ of $1 \times \mathrm{PBS}$ and incubated overnight at $4{ }^{\circ} \mathrm{C}$ before virus titration. The viral stocks were then vortexed for about $10 \mathrm{~s}$ before RNA extraction. Volumes of $350 \mu \mathrm{L}$ were supplemented with NucliSens $^{\circ}$ easyMAG ${ }^{\text {m }}$ lysis buffer (BioMérieux) up to $3 \mathrm{~mL}$ and subjected to the NucliSens $^{\circ}$ easyMAG ${ }^{\text {m }}$ platform for RNA extraction by the "off-board Specific A protocol" according to the manufacturer's instructions. Lastly, nucleic acids were eluted in $70 \mu \mathrm{L}$ of elution buffer and pooled to obtain a homogenized RNA stock. To avoid contamination of cellular DNA from the HAV and RV RNA stocks, the samples were treated with the Turbo DNase free-kit (Life Technologies) according to the manufacturer's instructions. The purified RNA stocks were quantified by measuring absorbance at $260 / 280 \mathrm{~nm}$ with a Nanodrop ND-100 (Thermoscientific, France) and the free software available on the "http://endmemo.com/bio/dnacopynum. php" website. All viral RNA stocks (from HAV, SA11 and Wa) containing $10^{9}$ copies / $\mu \mathrm{L}$ were aliquoted and stored at $-80^{\circ} \mathrm{C}$. 
Propidium monoazide (PMA), ethidium monoazide (EMA) PMA (phenanthridium, 3-amino-8-azido-5-[3-(diethylmethylammonio)propyl]-6-phenyl dichloride) was purchased from VWR (Fontenay sous Bois, France) at $20 \mathrm{mM}$ and diluted in ultra pure RNAse-free water to obtain the solutions used in this study. EMA (phenanthridium, 3-amino-8-azido5-ethyl-6-phenyl bromide) (Life Technologies) was dissolved in absolute ethanol to create the stock concentration of $5 \mathrm{mg} / \mathrm{mL}$ and then dissolved in ultra pure RNAse-free water to obtain the solutions used in this study. The EMA and PMA solutions were stored at $-20^{\circ} \mathrm{C}$ in the dark. All the experiments with dyes were performed in lighttransparent $1.5 \mathrm{~mL}$ microcentrifuge tubes (VWR).

\section{Binding of dyes to purified viral RNA}

The effect of several EMA and PMA treatment processes on $10^{8}$ copies genome of viral RNA (RV, HAV) in $100 \mu \mathrm{L}$ of phosphate-buffered saline (PBS) $1 \times, \mathrm{pH} 7.0$, were evaluated by testing several final dye concentrations $(10,20,50,100,200 \mu \mathrm{M})$, with incubation of $2 \mathrm{~h}$ at $4^{\circ} \mathrm{C}$ in the dark and sample exposure to light for $15 \mathrm{~min}$ using the LED-Active ${ }^{\odot}$ Blue system (IB - Applied Science, Barcelona, Spain). To determine whether PMA / EMA interfere with the ability of RT-qPCR to detect viruses, controls consisting of viral RNA that was treated with PMA / EMA without photoactivation were included with each dye concentration used. To attempt to remove the inhibitory effects of residual EMA / PMA on RT-qPCR, viral RNA treated with each dye concentration without photoactivation was purified using the QIAquick PCR purification kit (Qiagen, Courtaboeuf, France) according to the manufacturer's instructions. Finally, to determine the efficiency of each concentration of PMA / EMA tested, treated viral RNA samples were subjected to photoactivation before the purification step using the QIAquick PCR purification kit. The negative control was a non-treated $1 \times$ PBS sample. The positive control was a non-treated viral RNA sample in $1 \times$ PBS. A non-treated viral RNA control sample was subjected to the photoactivation step to check the effect of the lamp. Finally, all these samples were subjected to RNA detection by RT-qPCR assays A. The experiments were performed three times for all viral RNA.

\section{Determination of the optimal dye concentration for viruses}

The best dye (PMA / EMA) and its optimised concentration were determined for each viral target by testing five dye concentrations $(5 \mu \mathrm{M}, 20 \mu \mathrm{M}, 50 \mu \mathrm{M}, 75 \mu \mathrm{M}$, $100 \mu \mathrm{M})$. Briefly, in $100 \mu \mathrm{L}$ of $1 \times$ PBS samples of $10^{5}$ TCID $_{50}$ of RV (SA11), $10^{3}$ TCID $_{50}$ of RV (Wa) and $6 \times$ $10^{4} \mathrm{PFU}$ of HAV were conserved at $4^{\circ} \mathrm{C}$ or inactivated at $80^{\circ} \mathrm{C}$ for 10 minutes. Next, samples were incubated with different dye concentrations for $2 \mathrm{~h}$ at $4^{\circ} \mathrm{C}$ in the dark and then exposed to light for 15 min using the LEDActive $^{\circ}$ Blue system. The negative control was an untreated $1 \times$ PBS sample. The positive controls were the non-dye-treated viral samples kept at $4^{\circ} \mathrm{C}$ or inactivated at $80^{\circ} \mathrm{C}$ for 10 minutes, used to calculate the reduction rates of the viral load. To check the effect of the lamp, the non-dye-treated viral samples kept at $4^{\circ} \mathrm{C}$ or inactivated at $80^{\circ} \mathrm{C}$ for 10 minutes and subjected to the photoactivation step were used as the controls. To check the effect of the dyes, the viral samples at $4^{\circ} \mathrm{C}$ or inactivated at $80^{\circ} \mathrm{C}$ for 10 minutes treated with $50 \mu \mathrm{M}$ of dye without the photoactivation step were used as the controls.

Finally, all these samples were subjected to RNA extraction and detection by RT-qPCR assays A. The experiments were performed three times for each virus.

Evaluation of the combined effect of dyes and surfactants Tween 20 and IGEPAL CA-630 were purchased from Sigma-Aldrich (Saint-Quentin Fallavier, France) and Triton X-100 from Fisher Bioblock Scientific (Illkirch, France). These surfactants were dissolved in ultra pure RNAse-free water to obtain solutions at $1 \%$ and $10 \%$. In $100 \mu \mathrm{L}$ of $1 \times$ PBS, samples of $10^{5} \mathrm{TCID}_{50}$ of RV (SA11), $10^{3} \mathrm{TCID}_{50}$ of RV (Wa) and $6 \times 10^{4} \mathrm{PFU}$ of HAV were stored at $4^{\circ} \mathrm{C}$ or inactivated at $80^{\circ} \mathrm{C}$ for 10 minutes. The HAV and RV (Wa, SA11) samples were further treated with EMA $20 \mu \mathrm{M}$ to which different final concentrations $(0.1 \%, 0.5 \%$ and $1 \%)$ of the surfactants were added. The HAV and RV (SA11) samples were treated with PMA $50 \mu \mathrm{M}$ to which different concentrations $(0.1 \%, 0.5 \%$ and $1 \%$ ) of the surfactants were added. The RV (Wa) samples were treated with PMA $75 \mu \mathrm{M}$ to which different concentrations $(0.1 \%, 0.5 \%$ and $1 \%)$ of the surfactants were added. Next, the samples were incubated for $2 \mathrm{~h}$ at $4^{\circ} \mathrm{C}$ in the dark and then exposed to light for $15 \mathrm{~min}$ using the LED-Active ${ }^{\oplus}$ Blue system.

The negative control was a non-inactivated and untreated $1 \times$ PBS sample. For the experiments at $4^{\circ} \mathrm{C}$, the positive control was a non-inactivated and untreated virus sample incubated for $2 \mathrm{~h}$ at $4^{\circ} \mathrm{C}$. For the experiments at $80^{\circ} \mathrm{C}$, the positive control was an inactivated $(10 \mathrm{~min}$ at $80^{\circ} \mathrm{C}$ ) and untreated virus sample incubated for $2 \mathrm{~h}$ at $4^{\circ} \mathrm{C}$. All non-inactivated samples and positive controls were subjected to infectious titration to check the effect of the surfactants on the infectious viruses. Finally, all these samples were subjected to RNA extraction and detection by RT-qPCR assays A. The experiments were performed three times for each virus. Concentrations of the surfactant (Tween 20, Triton $\times 100$ and IGEPAL CA-630) added to the treated samples were applied to MA-104 cells in order to check their cytotoxicity (negative control). The experiments were performed three times for each virus. 


\section{Evaluation of the incubation time with dyes and surfactants}

The influence of the incubation time with dyes and surfactant were determined for HAV treated with EMA $20 \mu \mathrm{M}+$ IGEPAL CA-630 0.5\%, SA11 treated with PMA $50 \mu \mathrm{M}$ and Wa treated with EMA $20 \mu \mathrm{M}$. Briefly, samples of $10^{5} \mathrm{TCID}_{50}$ of RV (SA11), $10^{3} \mathrm{TCID}_{50}$ of RV (Wa) and $6 \times 10^{4} \mathrm{PFU}$ of HAV were stored in $100 \mu \mathrm{L}$ of $1 \times \mathrm{PBS}$ at $4^{\circ} \mathrm{C}$ or inactivated at $80^{\circ} \mathrm{C}$ for 10 minutes and were further incubated with the corresponding selected dyes and surfactants for $30 \mathrm{~min}, 2 \mathrm{~h}$ and overnight in the dark and then exposed to light for 15 min using the LED-Active ${ }^{\circ}$ Blue system.

The negative control was a non-inactivated and untreated $1 \times$ PBS sample incubated for $2 \mathrm{~h}$ at $4^{\circ} \mathrm{C}$. For the experiments at $4^{\circ} \mathrm{C}$, the positive control was a noninactivated and untreated virus sample incubated for $2 \mathrm{~h}$ at $4^{\circ} \mathrm{C}$. For the experiments at $80^{\circ} \mathrm{C}$, the positive control was an inactivated $\left(10 \mathrm{~min}\right.$ at $\left.80^{\circ} \mathrm{C}\right)$ and untreated virus sample incubated for $2 \mathrm{~h}$ at $4^{\circ} \mathrm{C}$. Additional controls were performed to check the effect of the IGEPAL CA-630 $0.5 \%$ alone on HAV regardless of the thermal inactivation and photoactivation. Finally, all these samples were subjected to RNA extraction and detection by RT-qPCR assays $\mathrm{A}$. The experiments were performed three times for each virus.

\section{Thermal inactivation of viruses}

Three series of HAV and RV strain (Wa, SA11) samples were inactivated thermally in $1 \times$ PBS by using a water bath set at $37^{\circ} \mathrm{C}$ and dry baths at $68^{\circ} \mathrm{C}, 72^{\circ} \mathrm{C}$ and $80^{\circ} \mathrm{C}$. Aliquots of $50 \mu \mathrm{L}$ of each virus were incubated for each temperature for $0,1,5,10$ and $20 \mathrm{~min}$. Then, $150 \mu \mathrm{L}$ of $1 \times \mathrm{PBS}$ at $4^{\circ} \mathrm{C}$ were added to the samples and placed on ice. The negative control was a non-inactivated and untreated $1 \times$ PBS sample. The positive control was a noninactivated and untreated virus sample stored at $4^{\circ} \mathrm{C}$. Three $100 \mu \mathrm{L}$ series of aliquots corresponding to $10^{5}$ $\mathrm{TCID}_{50}$ of RV (SA11), $10^{3} \mathrm{TCID}_{50}$ of RV (Wa) and $6 \times$ $10^{4}$ PFU of HAV were performed. The first series was kept to monitor loss of infectivity by performing virus titration on cells. The second series was subjected to direct RNA extraction. Finally, the third series was treated with selected dyes and surfactant. Typically, a final dye concentration of $20 \mu \mathrm{M}$ of EMA and IGEPAL CA-630 $0.5 \%$ were added to HAV aliquots, a final dye concentration of $20 \mu \mathrm{M}$ EMA was added to RV (Wa) aliquots, and a final dye concentration of $50 \mu \mathrm{M}$ of PMA was added to RV (SA11) aliquots. Then, all samples were incubated for $2 \mathrm{~h}$ at $4^{\circ} \mathrm{C}$ in the dark and then exposed to light for 15 min using the LED-Active ${ }^{\circ}$ Blue system. After photoactivation, the virus samples were also subjected to nucleic acid extraction. Finally, RNA extracts obtained from the second and third series were quantified by testing the three RT-qPCR assays designed for each viral target. The experiments were performed three times for each virus.

\section{Viral RNA extraction}

Nucleic acid extraction was performed in untreated virus samples and samples treated with dyes and surfactants. A hundred $\mu \mathrm{L}$ of the virus sample were supplemented with NucliSens $^{\circ}$ easyMAG ${ }^{\text {to }}$ lysis buffer (BioMérieux) up to $3 \mathrm{~mL}$ and subjected to the NucliSens ${ }^{\circ}$ easyMAG ${ }^{\mathrm{Tx}}$ platform for total nucleic acid extraction by the "off-board Specific A protocol" according to the manufacturer's instructions. Lastly, nucleic acids were eluted in $70 \mu \mathrm{L}$ of elution buffer and stored at $-80^{\circ} \mathrm{C}$.

\section{Primers and probes}

Three RT-qPCR assays targeting the non-coding region at the $5^{\prime}$ end (5'-NCR) of HAV which have been described by Costafreda et al. [38], and adapted from Costafreda et al. [38] and Di Pasquale et al. [39,40] were used. The sequences of the primer pairs and the TaqMan probes used were as follows:

The HAV RT-qPCR assay A generates amplification products of 174 bp [38] and was recommended in the CEN/ISO/TS 15216 (qualitative / quantitative methods) for detection of HAV in foodstuffs. The sense primer (HAV68) was 5 '-TCACCGCCGTTTGCCTAG-3', the antisense primer (HAV241) was 5'-GGAGAGCCCTGGAAGAAAG-3' and the TaqMan probe (HAV150 -) was 5'-FAM-CCTGA ACCTGCAGGAATTAA-MGB-3'.

HAV RT-qPCR assay B generates amplification products of $353 \mathrm{bp}$. It exhibits the same sense primer and probe as HAV RT-qPCR model A associated with another antisense primer named HAV-399R: 5' -GCCTAAGAGGTTTCACC CGTAG -3' designed with Beacon Designer software.

Finally, the HAV RT-qPCR assay C adapted from Di Pasquale et al. $[39,40]$ generates amplification products of $77 \mathrm{bp}$. The sense primer (HAVf ISS (459-478)) was 5'GCGGCGGATATTGGTGAGTT-3', the antisense primer (HAVr ISS (535-515)) was 5' - CAATGCATCCACTGGA TGAGA-3' and the TaqMan probe (HAVp ISS (484511)) was $5^{\prime}$ ROX- $\triangle$ GACAAAAACCATTCAACGCC GGAGGACT-BHQ2-3'. When comparing to the model published by Di Pasquale et al. [39,40], " $\Delta$ " corresponds to a deletion of 4 nucleotides and the nucleotides in bold corresponds to insertions.

Three RT-qPCR assays targeting the rotaviruses were used. The RT-qPCR assay which has been described by Pang et al. [41] in the NSP3 region was used with a sense primer slightly modified with degenerated bases for matching with both human and simian strains.

Thus, RV RT-qPCR assay A generates amplification products of $87 \mathrm{bp}$. The sense primer (Rota NVP3-F) (positions: 
963-982) was 5'-RYCATCTAYRCATRACCCTC-3', the antisense primer (Rota NVP3-R) (positions 1034-1049) was 5'-GGTCACATAACGCCCC-3' and the TaqMan probe (positions 984-1016) was 5' - FAM- ATGAGCACA ATAGTTAAAAGCTAACACTGTCAA-BHQ1-3'.

RV RT-qPCR assay $B$ generates amplification products of $313 \mathrm{bp}$. It exhibits the same antisense primer and probe as RV RT-qPCR assay A associated with another sense primer named Rota NSP3-736 F : 5'-GARTGG TATYTAAGATCWATGGAAT-3' designed with Beacon Designer software.

RV RT-qPCR assay C designed in the NSP4 region with Beacon Designer software generates amplification products of $352 \mathrm{bp}$. The sense primer (rotaNSP4_166$188 \mathrm{~F}$ ) was: 5' $^{\prime}$-ATTGCRYTGAAAACRTCAAAATG-3', the antisense primer (rotaNSP4_517-493R) was: 5' -GCA GTCACTTCTYTTGGTTCATAAG-3' and the TaqMan probe (rotaNSP4_486-462P) was 5'-ROX-YCCACTTT CCCAYTCTTCTAGCGTT-BHQ2-3'. Primers and probes were purchased from Eurofins (Les Ulis, France) and Applied Biosystems (Courtaboeuf, France).

\section{Real-time RT-qPCR conditions}

One-step RT-qPCR amplifications were performed in duplicate on a CFX96 ${ }^{\text {tim }}$ real-time PCR detection system from Bio-Rad (Marnes-la-Coquette, France). Reactions were performed in a $25 \mu \mathrm{L}$ reaction mixture containing $1 \times$ of thermoscript reaction mix, and $0.5 \mu \mathrm{L}$ of Thermoscript Plus / Platinum Taq enzyme mix, which are components of the Platinum ${ }^{\circ}$ Quantitative RT-PCR ThermoScript ${ }^{\mathrm{m}}$ One-Step System (Fisher Bioblock Scientific, Illkirch, France), as well as $2 \mathrm{U}$ RNAse inhibitor (Applied Biosystems), $5 \mu \mathrm{g}$ of BSA (Ambion), $500 \mathrm{nM}$ of forward primer, $900 \mathrm{nM}$ of reverse primer, $250 \mathrm{nM}$ of probe and $5 \mu \mathrm{L}$ of RNA extract. The one-step RT-qPCR program was as follows: $60 \mathrm{~min}$ reverse transcription of RNA at $55^{\circ} \mathrm{C}$, followed by a $15 \mathrm{~min}$ denaturation step at $95^{\circ} \mathrm{C}$, and finally 45 cycles of $15 \mathrm{~s}$ at $95^{\circ} \mathrm{C}, 1 \mathrm{~min}$ at $60^{\circ} \mathrm{C}$ and $1 \mathrm{~min}$ at $65^{\circ} \mathrm{C}$. The fluorescence was recorded at the end of the elongation steps $\left(1\right.$ minute at $\left.65^{\circ} \mathrm{C}\right)$ by the apparatus for each amplification cycle. $\mathrm{Ct}$ was defined as the PCR cycle at which the fluorescence intensity exceeded the threshold value. All samples were characterised by a corresponding $\mathrm{Ct}$ value. Negative samples gave no Ct value. A standard curve for each system was generated using 10-fold dilution of purified RNA. The slopes $(S)$ of the regression lines were used to calculate the amplification efficiency $(E)$ of the real-time qRT-PCR reactions, according to the formula: $E=10^{|-1 / s|}-1[42]$.

\section{Data analysis}

The viral titers were obtained with cell culture assay and RT-qPCR according to the pre-treatment. Virus inactivation was determined by calculating the $\log _{10}\left(\mathrm{~N}_{\mathrm{t}} / \mathrm{N}_{0}\right)$, where $\mathrm{N}_{0}$ is the titre of the virus recovered on the positive control and $\mathrm{N}_{\mathrm{t}}$ is the titre of the virus recovered on the tested sample.

Thermal inactivation kinetics were expressed as the virus survival ratio

$$
S_{i}(t)=\frac{N_{i}(t)}{N_{0}}
$$

where $\mathrm{N}_{\mathrm{i}}(\mathrm{t})$ is the virus concentration measured with method $i$ at time $t$ and $\mathrm{N}_{0}$ is the virus concentration obtained by the RT-qPCR method.

GInaFiT, a freeware Add-in for Microsoft ${ }^{\bullet}$ Excel developed by Geeraerd et al. [43] was used to model inactivation kinetics. GInaFiT makes it possible to choose from different types of microbial survival models (nine) according to different statistical criteria (i.e., sum of squared errors, mean sum of squared errors and its root, $R^{2}$, and adjusted $R^{2}$ ). According to these criteria, the "log-linear + tail" inactivation model was found to be the most appropriate for describing inactivation curves regardless of the virus and the temperature of inactivation.

The log-linear + tail model can be expressed as followed:

$$
\log _{10}\left(S_{i}(t)\right)=\log _{10}\left(\left(S_{i, 0}-S_{i, \text { res }}\right) \cdot \exp \left(-k_{\max } \cdot t\right)+S_{i, \text { res }}\right)
$$

where $k_{\max }\left(\min ^{-1}\right), S_{\mathrm{i}, \text { res }}$ and $S_{\mathrm{i}, 0}$ are the model parameters.

$k_{\max }$ is the first order inactivation constant, i.e. it characterizes the slope of the linear decrease of concentration expressed as a logarithm. $k_{\max }$ is directly linked to the $D$ value, the decimal reduction time, $k_{\max }=\ln (10) / D$. $S_{\mathrm{i}, \text { res }}$ characterizes the fraction of the population remaining constant in time, or, otherwise stated, not undergoing any significant subsequent inactivation regardless of the duration of the inactivation treatment. $S_{\mathrm{i}, 0}$ is the initial survival ratio.

This ratio was expected to be equal to zero if the RTqPCR method $(i=1)$ was used to quantify virus titer. $S_{\mathrm{i}, 0}$ can also help to quantify the difference between RTqPCR and pretreatment-RTqPCR $(i=2)$ or the cultural titration method $(i=3)$.

GInaFiT also returns the standard error values of the estimated parameter. These standard errors were used to construct asymptotic parameter confidence intervals. When no inactivation was observed, $k_{\max }$ and $S_{\mathrm{i} \text {,es }}$ were presented as zero with no confidence intervals, and the considered experiments were simply represented with $S_{\mathrm{i}, 0}$. When no quantification was possible after 1 minute of treatment, corresponding to very fast inactivation, the limit of quantification (LOQ) value was used to set a value for $k_{\max }$ and $S_{\mathrm{i}, \text { res }}$. $k_{\max }$ was set at its minimum possible value, $\ln (10)$. LOQ and $S_{\mathrm{i}, \text { res }}$ were set to their maximum 
possible value, i.e. LOQ. No confidence intervals were given for either parameter.

\begin{abstract}
Abbreviations
ATCC: American type culture collection; CEN: European committee for standardisation; dsRNA: Double-strand RNA; EMA: Ethidium monoazide; HAV: Hepatitis A virus; LOD: Limit of detection; LOQ: Limit of quantification; MEM: Minimum essential medium; NCR: Non-coding region; NoV: Norovirus: PBS: Phosphate-buffered saline; PCR: Polymerase chain reaction; PFU: Plaqueforming units; PMA: Propidium monoazide; RT-qPCR: Quantitative reverse transcriptase PCR; RV: Rotavirus; ssRNA: Single-strand RNA; TCID 50 : 50\% tissue culture infectious dose.
\end{abstract}

\section{Competing interests}

The authors declare that they have no competing interests.

\section{Authors' contributions}

CC and AF performed these experiments. LG performed statistical study. All authors wrote, read and approved the final manuscript.

\section{Acknowledgements}

This work is part of the thesis by Coralie Coudray-Meunier, a PhD student who received financial support from ANSES.

\section{Author details}

'ANSES, Food Safety Laboratory, Food and Water Virology Unit, 23 Avenue du Général de Gaulle, 94706 Maisons-Alfort cedex, France. ${ }^{2}$ ANSES, Food Safety Laboratory, Modelling of Bacterial Behaviour Unit, 23 Avenue du Général de Gaulle, 94706 Maisons-Alfort cedex, France.

Received: 19 June 2013 Accepted: 19 September 2013

Published: 1 October 2013

\section{References}

1. Koopmans M, Duizer E: Foodborne viruses: an emerging problem. Int $\mathrm{J}$ Food Microbiol 2004, 90:23-41.

2. Rodríguez-Lázaro D, Cook N, Ruggeri FM, Sellwood J, Nasser A, Nascimento MS, D'Agostino M, Santos R, Saiz JC, Rzeżutka A, Bosch A, Gironés R, Carducci A, Muscillo M, Kovač K, Diez-Valcarce M, Vantarakis A, Von Bonsdorff CH, De Roda Husman AM, Hernández M, Van der Poel WH: Virus hazards from food, water and other contaminated environments. FEMS Microbiol Rev 2012, 36:786-814.

3. Gulati BR, Allwood PB, Hedberg CW, Goyal SM: Efficacy of commonly used disinfectants for the inactivation of calicivirus on strawberry, lettuce, and a food-contact surface. J Food Prot 2001, 64:1430-1434.

4. Hirneisen KA, Black EP, Cascarino JL, Fino VR, Hoover DG, Kniel KE: Viral inactivation in foods: a review of traditional and novel food-processing technologies. CRFSFS 2010, 9:3-20.

5. Koopmans $\mathrm{M}$, Von Bonsdorff $\mathrm{CH}$, Vinjé J, De Medici D, Monroe S: Foodborne viruses. FEMS Microbiol Rev 2 2002, 6:187-205.

6. Sánchez G, Bosch A, Pintó RM: Hepatitis A virus detection in food: current and future prospects. Lett Appl Microbiol 2007, 45:1-5.

7. Stals A, Baert L, Van Coillie E, Uyttendaele M: Extraction of food-borne viruses from food samples: a review. Int J Food Microbiol 2012, 153:1-9.

8. Lees D, CEN WG6 TAG4: International standardization of a method for detection of human pathogenic viruses in molluscan shellfish. Food Environ Virol 2010, 2:146-155.

9. Hamza IA, Jurzik L, Überla K, Wilhelm M: Methods to detect infectious human enteric viruses in environmental water samples. Int $J$ Hyg Environ Health 2011, 214:424-436.

10. Lamhoujeb S, Fliss I, Ngazoa SE, Jean J: Evaluation of the persistence of infectious human noroviruses on food surfaces by using real-time nucleic acid sequence-based amplification. Appl Environ Microbiol 2008 74:3349-3355

11. Nuanualsuwan S, Cliver DO: Pretreatment to avoid positive RT-PCR results with inactivated viruses. J Virol Methods 2002, 104:217-225.

12. Topping JR, Schnerr H, Haines J, Scott M, Carter MJ, Willcocks MM, Bellamy K, Brown DW, Gray JJ, Gallimore Cl, Knight Al: Temperature inactivation of Feline calicivirus vaccine strain FCV F-9 in comparison with human noroviruses using an RNA exposure assay and reverse transcribed quantitative real-time polymerase chain reaction-A novel method for predicting virus infectivity. J Virol Methods 2009, 156:89-95.

13. Fittipaldi $M$, Nocker $A$, Codony F: Progress in understanding preferential detection of live cells using viability dyes in combination with DNA amplification. J Microbiol Methods 2012, 91:276-289.

14. Fujimoto J, Tanigawa K, Kudo Y, Makino H, Watanabe K: Identification and quantification of viable Bifidobacterium breve strain Yakult in human faeces by using strain-specific primers and propidium monoazide. J App/ Microbiol 2011, 110:209-217.

15. Josefsen MH, Löfström C, Hansen TB, Christensen LS, Olsen JE, Hoorfar J: Rapid quantification of viable Campylobacter bacteria on chicken carcasses, using real-time PCR and propidium monoazide treatment, as a tool for quantitative risk assessment. Appl Environ Microbiol 2010, 76:5097-5104.

16. Nocker A, Camper AK: Novel approaches toward preferential detection of viable cells using nucleic acid amplification techniques. FEMS Microbiol Lett 2009, 291:137-142

17. Yáñez MA, Nocker A, Soria-Soria E, Múrtula R, Martínez L, Catalán V: Quantification of viable Legionella pneumophila cells using propidium monoazide combined with quantitative PCR. J Microbiol Methods 2011, 85:124-130.

18. Nocker A, Cheung CY, Camper AK: Comparison of propidium monoazide with ethidium monoazide for differentiation of live vs. dead bacteria by selective removal of DNA from dead cells. J Microbiol Methods 2006, 67:310-320.

19. Kim K, Katayama H, Kitajima M, Tohya Y, Ohgaki S: Development of a realtime RT-PCR assay combined with ethidium monoazide treatment for RNA viruses and its application to detect viral RNA after heat exposure. Water Sci Technol 2011, 63:502-507.

20. Kim SY, Ko G: Using propidium monoazide to distinguish between viable and nonviable bacteria, MS2 and murine norovirus. Lett Appl Microbiol 2012, 55:182-188.

21. Parshionikar S, Laseke I, Fout GS: Use of propidium monoazide in reverse transcriptase PCR to distinguish between infectious and noninfectious enteric viruses in water samples. Appl Environ Microbiol 2010, 76:4318-4326.

22. Graiver DA, Saunders SE, Topliff CL, Kelling CL, Bartelt-Hunt SL: Ethidium monoazide does not inhibit RT-PCR amplification of nonviable avian influenza RNA. J Virol Methods 2010, 164:51-54.

23. Sánchez G, Elizaquível P, Aznar R: Discrimination of infectious hepatitis $A$ viruses by propidium monoazide real-time RT-PCR. Food Environ Virol 2012, 4:21-25.

24. Bertrand I, Schijven JF, Sánchez G, Wyn-Jones P, Ottoson J, Morin T, Muscillo M, Verani M, Nasser A, De Roda HAM, Myrmel M, Sellwood J, Cook N, Gantzer C: The impact of temperature on the inactivation of enteric viruses in food and water: a review. J Appl Microbiol 2012, 112:1059-1074.

25. Deboosere N, Pinon A, Delobel A, Temmam S, Morin T, Merle G, BlaiseBoisseau S, Perelle S, Vialette M: A predictive microbiology approach for thermal inactivation of Hepatitis A Virus in acidified berries. Food Microbiol 2010, 27:962-967.

26. Cliver DO: Capsid and infectivity in virus detection. Food Environ Virol 2009, 1:123-128

27. Stals A, Van Coillie E, Uyttendaele M: Viral genes everywhere: public health implications of PCR-based testing of foods. Curr Opin Virol 2013, 3:69-73.

28. Kusov YY, Gauss-Müller V: In vitro RNA binding of the hepatitis A virus proteinase $3 \mathrm{C}$ (HAV $3 \mathrm{Cpro}$ ) to secondary structure elements within the $5^{\prime}$ terminus of the HAV genome. RNA 1997, 3:291-302.

29. Contreras PJ, Urrutia H, Sossa K, Nocker A: Effect of PCR amplicon length on suppressing signals from membrane-compromised cells by propidium monoazide treatment. J Microbiol Methods 2011, 87:89-95.

30. Soejima T, Schlitt-Dittrich F, Yoshida S: Polymerase chain reaction amplification length-dependent ethidium monoazide suppression power for heat-killed cells of Enterobacteriaceae. Anal Biochem 2011, 418:37-43.

31. Luo JF, Lin WT, Guo Y: Method to detect only viable cells in microbial ecology. Appl Microbiol Biotechnol 2010, 86:377-384.

32. Hollinger FB, Emerson SU: Hepatitis A virus. In Fields Virology. Edited by Knipe DM. Philadelphia, PA: Lippincott Williams and Wilkins; 2007:911-947.

33. Mathis PK, Ciarlet M, Campbell KM, Wang S, Owen KE, Ranheim TS: Separation of rotavirus double-layered particles and triple-layered particles by capillary zone electrophoresis. J Virol Methods 2010, 169:13-21.

34. Estes MK: Rotaviruses and their replication. In Fields Virology. 3rd edition. Edited by Fields BN, Knipe DN, Howley PM, Chanock RM, Melnick JL, 
Monath TP, Roizman B, Straus SE. Philadelphia, Pa: Lippincott-Raven; 1996:1625-1655.

35. Lemon SM, Murphy PC, Shields PA, Ping LH, Feinstone SM, Cromeans T, Jansen RW: Antigenic and genetic variation in cytopathic hepatitis A virus variants arising during persistent infection: evidence for genetic recombination. J Virol 1991, 65:2056-2065.

36. Cromeans T, Sobsey MD, Fields HA: Development of a plaque assay for a cytopathic, rapidly replicating isolate of hepatitis A virus. J Med Virol 1987, 22:45-56.

37. Dubois E, Hennechart C, Deboosere N, Merle G, Legeay O, Burger C, Le Calvé $\mathrm{M}$, Lombard B, Ferré V, Traoré $\mathrm{O}$ : Intra-laboratory validation of a concentration method adapted for the enumeration of infectious F-specific RNA coliphage, enterovirus, and hepatitis A virus from inoculated leaves of salad vegetables. Int J Food Microbiol 2006, 108:164-171.

38. Costafreda MI, Bosch A, Pinto RM: Development, evaluation and standardization of a real time TaqMan reverse transcription-PCR assay for quantification of hepatitis A virus in clinical and shellfish samples. Appl Environ Microbiol 2006, 72:3846-3855.

39. Di Pasquale S, Paniconi M, De Medici D, Suffredini E, Croci L: Duplex real time PCR for the detection of hepatitis A virus in shellfish using feline calicivirus as a process control. J Virol Methods 2010, 163:96-100.

40. Di Pasquale S, Paniconi M, Auricchio B, Orefice L, Schultz AC, De Medici D: Comparison of different concentration methods for the detection of hepatitis A virus and calicivirus from bottled natural mineral waters. J Virol Methods 2010, 165:57-63.

41. Pang XL, Lee B, Boroumand N, Leblanc B, Preiksaitis JK, Yu Ip CC: Increased detection of rotavirus using a real time reverse transcription-polymerase chain reaction (RT-PCR) assay in stool specimens from children with diarrhea. J Med Virol 2004, 72:496-501.

42. Tichopad A, Dilger M, Schwarz G, Plaffl MW: Standardized determination of real-time PCR efficiency from a single reaction set-up. Nucleic Acids Res 2003, 31(20):e122. Erratum in: Nucleic Acids Res 2003, 31 (22), 6688.

43. Geeraerd AH, Valdramidis VP, Van Impe JF: GInaFiT, a freeware tool to assess non-log-linear microbial survivor curves. Int J Food Microbiol 2005, 102:95-105. Erratum in: 2006. Int J Food Microbiol 110: 297

Cite this article as: Coudray-Meunier et al: Discrimination of infectious hepatitis $A$ virus and rotavirus by combining dyes and surfactants with RT-qPCR. BMC Microbiology 2013 13:216.

\section{Submit your next manuscript to BioMed Central and take full advantage of:}

- Convenient online submission

- Thorough peer review

- No space constraints or color figure charges

- Immediate publication on acceptance

- Inclusion in PubMed, CAS, Scopus and Google Scholar

- Research which is freely available for redistribution 